\title{
Probable Atherogenic Role of Zinc and Copper as Studied in Chronic Hemodialysis Patients
}

\author{
Shinichi Okuyama, Hitoshi Mishina, Kenji Hasegawa, \\ Nobumichi NaKano and Kazuhisa Ise \\ Department of Radiology, Occupational Health Center and \\ Department of Urology, Tohoku Rosai Hospital, Sendai 980
}

\begin{abstract}
Okuyama, S., Mishina, H., Hasegawa, K., Nakano, N. and Ise, K. Probable Atherogenic Role of Zinc and Copper as Studied in Chronic Hemodialysis Patients. Tohoku J. exp. Med. 1982, 138 (2), 227-229 — The relationship of lipoperoxidemia and HDL-cholesterolemia to circulating zinc and copper was investigated in patients undergoing chronic hemodialysis. When the serum zinc level was low and the copper level was high, or when the zinc/copper ratio was low, decreased concentrations of HDL-cholesterole were observed. In view of the high incidence of atherosclerosis among patients undergoing chronic hemodialysis, zinc and copper may somehow contribute to atherogenesis by affecting the serum HDL-cholesterol concentrations. atherogenesis; hypozincemia; hypercupremia; hypo-HDL-cholesterolemia; serum zinc/copper ratio
\end{abstract}

Heavy metals, especially zinc and copper, are contained in such enzymes as superoxide dismutase that can be involved in atherogenesis by controlling superoxide radicals (Bus et al. 1974; Wilson et al. 1978; Oberley and Buettner 1979). A high incidence of atherosclerosis has been known among patients on prolonged uremia hemodialysis (Lindner et al. 1974). The present investigation was undertaken to clarify the relationship of lipoperoxidemia and HDL-cholesterolemia to circulating zinc and copper in cases of chronic uremia hemodialysis.

\section{Materials and Methods}

The studies were carried out on 13 (8 male and 5 female) uremia patients who had been placed on chronic hemodialysis at Tohoku Rosai Hospital, Sendai, for 2 years and 2 months \pm 1 year and 7 months (mean \pm s.D.). Their average age was $50 \pm 14$ years. Their fundoscopic findings were those of atherosclerosis (as graded by Keith-Wagener's criteria, nil for I, 5 for II, 7 for III and $!$ for IV). Seven male and 1 female healthy laboratory personnel served as controls. Their average age was $35 \pm 11$ years.

Serum zinc and copper concentrations were estimated by atomic photoabsorptiometry. High density lipoprotein-cholesterol (HDL-cholesterol) was determined by a heparin-Ca, resin method (Noma et al. 1978). Lipoperoxide concentrations were determined by Yagi's method (1975) and were expressed in terms of malondialdehyde.

Received for publication, February 8, 1982.

Request for reprints to: Shinichi Okuyama, M.D., Ph. D., Department of Radiology, Tohoku Rosai Hospital, Sendai 980, Japan. 


\section{Results and Discussion}

Table 1 shows HDL-cholesterol levels which vary along with the serum zinc and copper concentrations. In the hemodialysis group, the serum copper concentrations were elevated and the zinc concentrations lowered so as to result in a reduction of the zinc/copper ratio from 0.9 to $0.59(p<0.005)$. A concomitant reduction of HDL-cholesterol concentrations was observed in them.

Thus, chronic hemodialysis of uremic patients is accompanied by an elevation of serum copper concentration and decreases in serum zinc level and serum HDL-cholesterol concentration. Hypo-HDL-cholesterolemia was observed consistently when serum zinc concentrations were lowered, absolute copper levels were elevated, or the serum zinc/copper ratio was reduced. The reduction of serum HDL-cholesterol was not observed, however, in those patients who had been placed on hemodialysis only for a period less than 1 year in spite of the similar alterations in the serum zinc and copper or the zinc/copper ratio. Hypo-HDLcholesterolemia was noted in chronic renal insufficiency (Itakura 1979), or following carbohydrate loading (Iwasaki and Aono 1981). Carbohydrate loading also induces hypozincemia (Davies et al. 1968) which may entice hypo-HDL-cholesterolemia. Phospholipase $\mathrm{A}_{2}$ (lecithinase A) is characterized by its zinc apposition (Karcioglu and Sarper 1980). Its enzymatic activity may be affected by zinc depletion and also by substitution with copper or excessive zinc (Wells 1972). Hyperzincemia experiments performed by Hooper et al. (1980) and probably those by Klevay (1973) seem to agree with this assumption. We may suppose that this enzyme would possibly regulate the phospholipid metabolism so as to affect the HDL-cholesterolemia because the phospholipids are major components of HDL-cholesterol.

We do not know whether or not the hemodialysis per se intensifies uremic hypozincemia. Nevertheless, the persistent hypozincemia would probably accelerate atherogenesis in patients on chronic hemodialysis. An atherogenic role of zinc thus may deserve further investigations.

TABLE 1. Atherogenic significance of serum zinc and copper concentrations and zinc/copper ratio as studied in the chronic uremic hemodialysis patients

\begin{tabular}{cccccc}
\hline & $\begin{array}{c}\text { Serum zinc } \\
(\mu \mathrm{g} / 100 \mathrm{ml})\end{array}$ & $\begin{array}{c}\text { Serum copper } \\
(\mu \mathrm{g} / 100 \mathrm{ml})\end{array}$ & $\begin{array}{c}\text { Zinc/copper } \\
\text { ratio }\end{array}$ & $\begin{array}{c}\text { HDL-cholesterol } \\
(\mathrm{mg} / 100 \mathrm{ml})\end{array}$ & $\begin{array}{c}\text { Lipoperoxide } \\
\text { (nmol/ml of } \\
\text { malondialdehyde) }\end{array}$ \\
\hline $\begin{array}{c}\text { Healthy controls } \\
(n=8)\end{array}$ & $79.9 \pm 13.4$ & $91.1 \pm 16.6$ & $0.91 \pm 0.25$ & $52.5 \pm 16.9$ & $3.5 \pm 1.1$ \\
$\begin{array}{c}\text { Hemodialytics } \\
(n=13)\end{array}$ & $60.4 \pm 15.0 \dagger$ & $111.2 \pm 25.7^{*}$ & $0.59 \pm 0.22_{+}^{+}$ & $35.2 \pm 10.5 \dagger$ & $\begin{array}{c}4.4 \pm 2.2 \\
\text { n.s. }\end{array}$ \\
\hline
\end{tabular}

Significantly different from control: $* p<0.05, \dagger p<0.01, \ddagger p<0.005$. n.s., not significant.

\section{References}

1) Bus, J.S., Aust, S.D. \& Gibson, J.E. (1974) Superoxide- and singlet oxygen-catalyzed lipid peroxidation as a possible mechanism for paraquat (methyl viologen) toxicity. Biochem. biophys. Res. Commun., 58, 749-755. 
2) Davies, I.J.T., Musa, M. \& Dormandy, T.L. (1968) Measurements of plasma zinc. $J$. clin. Path., 21, 359-365.

3) Hooper, P.L., Visconti, L., Garry, P.J. \& Johnson, G.E. (1980) Zine lowers highdensity lipoprotein-cholesterol levels. J. Amer. med. Ass., 244, 1960-1961.

4) Itakura, H. (1979) HDL estimation. Nippon Rinsyo, 37, Suppl., 1752-1755. (Japanese)

5) Iwasaki, Y. \& Aono, M. (1981) Effects of sucrose and invert sugar on the levels of plasma lipids, plasma apo A concentrations and chemical composition of high density lipoprotein subfractions in healthy young males. Proc. Jap. med. Ass., 70, 1105-1111. (Japanєse)

6) Karcioglu, Z.A. \& Sarper, R.M. (1980) Zinc and Copper in Medicine, Thomas, Springfield.

7) Klevay, L.H. (1973) Hypercholesterolemia in rats produced by an increase in the ratio of zinc to copper ingested. Amer. J. clin. Nutr., 16, 1060-1068.

8) Lindner, A., Charra, B., Sherrard, D.J. \& Scribner, B.H. (1974) Accelerated atherosclercsis in prolonged maintenance hemodialysis. New Engl. J. Med., 290, $697-701$.

9) Noma, A., Nezu-Nakayama, K., Kita, M. \& Okabe, H. (1978) Simultaneous determination of serum cholesterol in high- and low-density lipoproteins with use of heparin, $\mathrm{Ca}^{2+}$, and anion exhange resin. Clin. Chem., 29, 1504-1508.

10) Oberley, L.W. \& Buettner, G.R. (1979) Role of superoxide dismutase in cancer: A review. Cancer Res., 39, 1141-1149.

11) Wells, M.A. (1972) A kinetic study of the phospholipase $A_{2}$ (crotalus admanteus) catalyzed hydrolysis of 1,2-dibutyl-sn-glycerol-3-phosphorylcholine. Biochemistry, 11, 1030-1041.

12) Wilson, R.B., Middleton, C.C. \& Sun, G.Y. (1978) Vitamin E, antioxidants and lipid peroxidation in experimental atherosclerosis of rabbits. J. Nutr., 108, 1858-1867.

13) Yagi, K. (1975) Microassay of plasma lipoperoxides. Igaku-no-Ayumi, 950, 93-94. (Japanese) 